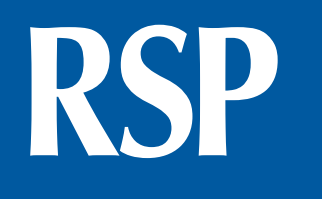

http://www.rsp.fsp.usp.br/

\title{
Assessment in the primary care of the State of São Paulo, Brazil: incipient actions in sexual and reproductive health
}

\author{
Mariana Arantes Nasser', Maria Ines Battistella Nemes", Marta Campagnoni Andrade"II, \\ Rogério Ruscitto do Prado ${ }^{\text {Iv }}$, Elen Rose Lodeiro Castanheirav \\ I Centro de Saúde Escola Professor Samuel Barnsley Pessoa. Faculdade de Medicina. Universidade de São Paulo. \\ São Paulo, SP, Brasil \\ " Departamento de Medicina Preventiva. Faculdade de Medicina. Universidade de São Paulo. São Paulo, SP, Brasil \\ II' Departamento de Saúde Coletiva. Faculdade de Ciências Médicas da Santa Casa de São Paulo. São Paulo, SP, Brasil \\ iv Departamento de Cardiologia. Hospital Israelita Albert Einstein. São Paulo, SP, Brasil \\ $\checkmark$ Departamento de Saúde Pública. Faculdade de Medicina de Botucatu. Universidade Estadual Paulista. \\ Botucatu, SP, Brasil
}

\section{ABSTRACT}

OBJECTIVE: The objective of this study is to assess performance in sexual and reproductive health of primary health care services of the Brazilian Unified Health System, in the State of São Paulo, Brazil.

METHODS: An evaluative framework was built for sexual and reproductive health with the categorization of 99 indicators in three domains: sexual and reproductive health promotion (25), sexually transmitted infections/AIDS prevention and care (43), and reproductive health care (31). This framework was applied to assess the services responses to the questionnaire of Quality Evaluation of Primary Health Care in the Municipalities of São Paulo State (QualiAB), in 2010. Percentages were calculated for positive responses to indicators and performance in the sexual and reproductive health dimension, according to domains, and their contribution to the overall score in sexual and reproductive health (Friedman), relative participation (Dunn), and correlation (Spearman) was verified.

Correspondence:

Mariana Arantes Nasser Av. Vital Brasil, 1490 Butantã 05503-000 São Paulo, SP, Brasil E-mail: manasser@usp.br

Received: Sept 25, 2015 Approved: May 26, 2016

How to cite: Nasser MA, Nemes MIB, Andrade MC, Prado RR, Castanheira ERL. Assessment in the primary care of the State of São Paulo, Brazil: incipient actions in sexual and reproductive health. Rev Saude Publica. 2017;51:77.

Copyright: This is an open-access article distributed under the terms of the Creative Commons Attribution License, which permits unrestricted use, distribution, and reproduction in any medium, provided that the original author and source are credited.

RESULTS: Overall, 2,735 services participated in the study. They were located in 586 municipalities (distributed throughout the 17 regional health departments of São Paulo), of which $70.6 \%$ had fewer than 100,000 inhabitants. The overall average performance of these services for sexual and reproductive health is $56.8 \%$. The actions are characterized by: prenatal with adequate beginning and exams, better organization for immediate rather than for late postnatal care, and selective reproductive planning for some contraceptives; prevention based on specific protection, limitations in the prevention of congenital syphilis, in the treatment of sexually transmitted infections, and in the screening of cervical and breast cancer; specific educational activities, with a restricted vulnerability approach, focus on sexuality over reproduction. The domain of reproductive health has greater participation in the overall score, followed by prevention/care and promotion. The three domains are correlated; the domain of prevention/care has the highest correlation with the other ones.

CONCLUSIONS: The implementation of sexual and reproductive health in primary health care in the services studied is incipient. The revision of the purpose of the work, the dissemination of technologies, and the investing in permanent education are needed. The evaluative framework built can be used by the sexual and reproductive health program services and management in primary health care, thereby contributing to their actions.

DESCRIPTORS: Program Evaluation. Health Services Evaluation. Sexual and Reproductive Health. Sexually Transmitted Diseases, prevention \& control. Acquired Immunodeficiency Syndrome, prevention \& control. Primary Health Care. Unified Health System. 


\section{INTRODUCTION}

Primary health care (PHC) services are considered relevant to sexual and reproductive health (SRH) of individuals and population groups. The Program of Action of the IV International Conference on Population and Development ${ }^{33}$ and the Platform of Action of the IV World Conference on Women ${ }^{32}$, international milestones in the definition and visibility of SRH, point to PHC as a priority level. In Brazil, PHC is strategic to make SRH policies effective in the Brazilian Unified Health System (SUS) ${ }^{12,22}$.

The policy recommendations and delineation of the SRH programs are related to the attributes and purposes of the work in $\mathrm{PHC}^{3,15,29}$. Considered as "first and basic care", $\mathrm{PHC}$ is characterized by its technological dimension ${ }^{15}$, the articulation of low-complexity material technologies and highly complex technical and organizational process technologies ${ }^{29}$, with the capacity to promote higher equality and efficiency to the health care system and a positive impact on the health of the population ${ }^{30}$. Oriented towards comprehensivenes ${ }^{3}$, it develops actions for health promotion, disease prevention, recovery, and rehabilitation. Because of its proximity to the territory - area of sanitary responsibility and geopolitical space $^{25}$, headquarters of the life of subjects, with its needs and projects -, PHC is the preferable scenario of care practices ${ }^{3,25,29,30}$. Issues related to sexuality and reproduction trigger individual demands and requests from other sectors for PHC services; they have epidemiological relevance and are of collective interest for health education in the community ${ }^{13,22}$.

The constitution of the SRH field refers to expanded notions of health and sexual and reproductive rights, influenced by population and development policies, and the participation of social movements about sexuality and gender relations ${ }^{7}$. Reproductive health is considered the complete well-being of the reproductive functions and processes; its care includes methods, techniques, and services that contribute to the reproductive well-being and the prevention and resolution of problems. Sexual health aims to improve the quality of life and personal relations. It is not limited to reproductive counseling and assistance to persons with sexually transmitted infections (STI) ${ }^{7}$.

Brazil, a signatory of international conferences on rights in $\mathrm{SRH}^{32,33}$, has elaborated policies, programs, protocols, and recommendations related to the attributions of PHC to make SRH effective in the SUS, which guided this evaluative study9. Examples include the National Policies on STI and AIDS ${ }^{16}$, Comprehensive Care for Women's Health ${ }^{17}$, Sexual Rights and Reproductive Rights ${ }^{18}$, Comprehensive Care for Men's Health ${ }^{21}$, Primary Health Care ${ }^{23}$, Comprehensive Health of Lesbians, Gays, Bisexuals, Transvestites, and Transsexuals ${ }^{24}$, Legal Framework "Health, a Right of Adolescents" ${ }^{20}$, and the Notebooks of Primary Health Care 18, "HIV/AIDS, Hepatitis, and other STI"19 and 26, "Sexual and Reproductive Health"22.

In the State of São Paulo, PHC is characterized by the presence of an old, wide, heterogeneous network of services ${ }^{5}$; the central technical areas, such as the STI/AIDS State Program, are also traditional. Being a pioneer program in the country, it has integrated actions with PHC since $2000^{26}$.

Implementation of SRH care in PHC presents challenges such as: lack of discussion on this topic in health training ${ }^{1}$; difficulties in how professionals address this issue with users ${ }^{13,22}$; limited understanding of the SRH contents as basic health action $\mathrm{s}^{22}$; low integration between services $^{34}$; focus on higher-risk groups over population strategies ${ }^{34}$; and little technological definition of prevention actions for STI and AIDS $^{12}$, characterized by the individual values of professionals and conservatism ${ }^{12}$. In Brazil and in the State of São Paulo, proposals to overcome these challenges include publications, seminars, permanent education activities, and monitoring of the actions in PHC services ${ }^{18,22,26}$.

This article has the objective to assess the SRH performance of PHC services in the SUS in the State of São Paulo; it integrates the research Quality Evaluation of Primary Health Care in the Municipalities of São Paulo State (QualiAB), particularly, the Evaluation of SRH implementation in the PHC in the State of São Pauloa. 


\section{METHODS}

This study was developed as a health assessment with the creation of an evaluative framework for the SRH dimension in PHC. The answers to the questionnaire QualiAB, filled online by managers and services teams, in 2010, were used as source of data. The questionnaire was elaborated in evaluative research ${ }^{5}$, validated in 2007, and referenced by the health work theory - which considers health practices as technical and political intervention in reality ${ }^{15}$. The QualiAB is applicable to services of different organizational arrangements and it covers the various tasks of the PHC, enabling the assessment of specific themes ${ }^{5}$.

In 2010, the QualiAB was adopted as a tool to support the PHC management of the State Health Department (SES/SP) 5 . Adherence was open for all the municipal managers to register their services in the QualiAB system, and its dissemination predominantly focused on municipalities that had the Program of Primary Health Care Articulators, aimed at municipalities with less than 100,000 inhabitants².

The evaluative framework for the SRH dimension consisted of the selection of answers to the questions of the QualiAB related to SRH, regarded as indicators and categorized according to the purposes of SRH promotion, STI/AIDS prevention and care, and reproductive health care (Table 1).

In order to characterize the practices of the services, the answers to the indicators generated a binary system ( 1 for what the service does; 0 for what it does not do). In each service, the answers to the indicators making up each subdomain were added; the total number of indicators making up the subdomain was the denominator for the value obtained, with the result varying between zero and 100. This procedure was repeated for each domain and for the SRH dimension, as a whole. Friedman test was used to compare the subdomains and domains in order to verify their contribution to the score created for the SRH dimension. A histogram was designed to show the distribution of services in the score for the SRH dimension. The relative participation of each domain or subdomain for the entire SRH dimension was subsequently obtained using Dunn's nonparametric multiple comparisons

Table 1. Number of indicators for assessment of the sexual and reproductive health (SRH) dimension in primary health care (PHC), according to domains and subdomains.

Assessment framework for the SRH dimension in PHC

\begin{tabular}{|c|c|c|c|}
\hline Purpose of the actions in PHC & Domain & Subdomain & $\begin{array}{l}\text { Indicator } \\
\text { (n) }\end{array}$ \\
\hline \multirow{3}{*}{$\begin{array}{l}\text { Well-being in the experience of sexuality and reproduction, with health } \\
\text { education, individual empowerment, community participation and } \\
\text { intersectoral activities. Guidance from the perspectives of human rights, } \\
\text { vulnerability, sexual and reproductive rights, and gender. }\end{array}$} & \multirow{3}{*}{$\begin{array}{l}\mathrm{SRH} \\
\text { promotion }\end{array}$} & Health education and networking opportunities & 8 \\
\hline & & $\begin{array}{l}\text { Investigation of situations of vulnerability and } \\
\text { measures to overcome them }\end{array}$ & 13 \\
\hline & & Body, sexuality, and reproduction approach & 4 \\
\hline Total indicators in the domain of SRH promotion & & & 25 \\
\hline \multirow{3}{*}{$\begin{array}{l}\text { Prevention, diagnosis of STI/AIDS, care and support for individuals, } \\
\text { considering the concept of vulnerability in their individual, social, and } \\
\text { programmatic aspects, coordination with other services and sectors, } \\
\text { importance of strategies for compliance, and contributions of health } \\
\text { surveillance and information activities. }\end{array}$} & \multirow{3}{*}{$\begin{array}{c}\text { STI/AIDS } \\
\text { prevention } \\
\text { and care }\end{array}$} & STI/AIDS prevention and diagnosis & 23 \\
\hline & & $\begin{array}{l}\text { Treatment, partnership with other services, } \\
\text { and support to patients with STI/AIDS }\end{array}$ & 11 \\
\hline & & $\begin{array}{l}\text { Health information and surveillance with } \\
\text { opportunity for STI/AIDS prevention }\end{array}$ & 9 \\
\hline Total indicators in the domain of STI/AIDS prevention and care & & & 43 \\
\hline \multirow{3}{*}{$\begin{array}{l}\text { Health education and guarantee of reproductive choices, based on the } \\
\text { perspectives of sexual and reproductive rights, and gender relations; } \\
\text { prenatal and postnatal care for the family, women's and children's } \\
\text { health, children, and families; reduction of morbidity and mortality; and } \\
\text { humanization and attention to health care of reproductive and sexually } \\
\text { related organs, including screening and diagnosis of neoplasms. }\end{array}$} & \multirow{3}{*}{$\begin{array}{l}\text { Reproductive } \\
\text { health care }\end{array}$} & Reproductive planning & 13 \\
\hline & & Prenatal and postnatal care & 12 \\
\hline & & $\begin{array}{c}\text { Health care of reproductive and sexually } \\
\text { related organs }\end{array}$ & 6 \\
\hline Total indicators in the domain of reproductive health care & & & 31 \\
\hline Total indicators in the SRH dimension & & & 99 \\
\hline
\end{tabular}

Source: the authors, based on the study of Nasser MA (see footnote) and QualiAB 2010.

STI: Sexually Transmitted Infections; QualiAB: Questionnaire of Quality Evaluation of Primary Health Care in the Municipalities of São Paulo State 
for repeated measures. Spearman correlations were calculated to identify the existence of correlations between subdomains, domains, and the SRH dimension.

The QualiAB research, including this study, is in conformity with the standards of research ethics (CEP UNESP 435/2005; CEP FMUSP 471631/2013). Municipal managers agreed by term of compliance; the services participating signed the informed consent.

\section{RESULTS}

From the 645 municipalities in the State of São Paulo, 586 (90.8\%) were part of the QualiAB assessment, with the registration of 2,844 services, of which, 2,735 services (95\%), distributed throughout the 17 Regional Health Departments of SES/SP, responded to the QualiAB ${ }^{5}$. According to population data of $2010,55.6 \%$ of the participating services are located in municipalities with less than 50,000 inhabitants, $15.1 \%$ between 50,000 and $100,000,12.7 \%$ between 100,000 and $200,000,11.6 \%$ between 200,000 and 500,000, and 5.1\%, with more

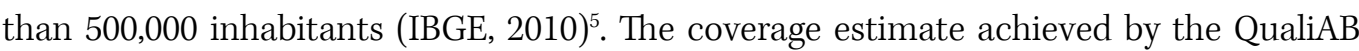
is imprecise, because of consistencies in the existing records and their poor updating. Considering the number of 4,222 basic health units and 341 health centers, amounting to 4,563 basic services, registered in the National Register of Health Establishments in July 2010, the proportion of response to the QualiAB is $59.9 \%$ of the existing services.

Of the participating services, $56.6 \%$ are located in the urban periphery, $33.9 \%$ in the urban center, and $9.5 \%$ in the rural area. The distribution by organizational arrangement consists of 43.7\% of Family Health Units (FHU), 32.0\% of Basic Health Units (BHU), with or without specialties, $8.5 \%$ of BHU with Program of Community Health Agents (PCHA), 5.6\% of BHU with family health team, $4.5 \%$ of BHU with specialties, $0.7 \%$ of upfront units, and $5.0 \%$ of other types.

The SRH actions developed in the PHC and the average performance of the group of services are presented in the domains of SRH promotion, STI/AIDS prevention and care, and reproductive health care (Table 2).

For SRH promotion, isolated activities are predominant in the actions of health education developed in the community and unit: campaigns restricted to the health service and sector, based on the transmission of information. Addressing the body and reproductive functions takes precedence over the discussion on rights and sexuality. Situations of vulnerability, such as alcohol abuse and violence, are more present in educational activities in the community than they are followed up in the units.

Regarding STI/AIDS prevention and care, specific protection actions, such as vaccination against hepatitis $\mathrm{B}$ and distribution of condoms to the general population, are among the main preventive measures, despite the scarce availability of female condoms. Educational activities for STI/AIDS prevention are more often in the units than in the community. Women are the main target audience, comparing adults and adolescents. There are limitations of screening for cervical-uterine cancer, because of the low criteria compliance and irregular offer of Pap smear. Syphilis and HIV diagnosis, during prenatal care, is compromised by improper collection of exams. Treatment of STI cases has limitations because of the insufficient adoption of syndromic treatment and the predominance of a diagnostic confirmation approach, requiring greater professional expertise and bringing risks to the adherence of the user. Use of condoms and serological testing are frequently advised. There are limitations in the availability of medications for STIs, the application of benzathine penicillin, and the treatment of pregnant women with syphilis and their partners. The nonexistence of cases of congenital syphilis is reported only in part of the units. Health surveillance activities, such as exam assessment, happen partially. The most frequently recorded information, such as vaccinations and collection of Pap smear, refers to productivity.

In reproductive health care, reproductive planning is a frequent activity in women's health care, with a higher occurrence of health educational activities in the units than in the community. 
Table 2. Percentage of primary health care (PHC) services of the State of São Paulo, Brazil that report the fulfillment of sexual and reproductive health $(\mathrm{SRH}) *$ actions in 2010. $(\mathrm{n}=2,735)$

\begin{tabular}{l}
\hline Subdomains \\
\hline Health education and networking opportunities \\
Investigation of situations of vulnerability and \\
measures to overcome them
\end{tabular}
measures to overcome them

Body, sexuality, and reproduction approach

Domain of sexual and reproductive health promotion

Annual thematic campaigns

Educational activities with local institutions

Educational activities with municipal departments

58.5

Waiting room: discussions proposed by patients

46.2

Health education for adolescents in schools

Educational activities on violence (C)

Educational activities on alcohol and drugs (C)

Care for the elderly includes guidelines on rights

Diagnosis, guidance, and follow-up of cases of alcoholism (U)

Diagnosis, guidance, and follow-up of women in situation of violence $(U)$

33.9

Guidance on development/changes in adolescence

24.1

35.5

38.5

Care for the elderly includes approach to climacteric

10.5

21.7

38.8

Care for the elderly includes approach to sexuality

52.0 Domain of STI/AIDS prevention and care

Application of vaccine for Hepatitis B (U)

36.1

STI/AIDS prevention (C)

74.5

STI/AIDS prevention $(U)$

70.2

Adequacy of criteria for collecting Pap smear

80.3

Opportunities for Pap smear collection

5.4

Women's health includes STI/AIDS prevention

45.7

STI/AIDS prevention and diagnosis

Education on sexuality and STI/AIDS prevention for adolescents

86.4

STI/AIDS counseling for adults

60.8

Two serologies for syphilis and HIV in prenatal care

64.8

Distribution of condoms to the general population, according to demand

Distribution of condoms includes female condoms

92.8

Application of penicillin - routine procedure

Treatment of syphilis in pregnant women and their partners (U)

Available drugs to treat STI

Treatment, partnership with other services, and In case of STI hypothesis: research, diagnosis, treatment (U)

26.8

41.6

46.1

support to patients with STI/AIDS

In case of STI hypothesis: syndromic treatment (U)

47.0

67.4

In case of STI hypothesis: condom counseling (U)

38.1

$\begin{array}{ll}\text { In case of STI hypothesis: serological testing counseling (U) } & 71.5\end{array}$

Record of the number of vaccinations

73.6

Record of the number of Pap smears

91.2

Test results monitoring upon arrival $(U)$

49.9

opportunity for STI/AIDS prevention

Nonexistence of congenital syphilis in prenatal $(U)$, in 3 years

64.4

Family planning education $(\mathrm{C})$

Family planning education $(\mathrm{U})$

72.5

Oral contraceptive available in the last 6 months

83.4

Injectable contraceptive available in the last 6 months

72.8

Male condoms available in the last 6 months

94.9

Female condoms available in the last 6 months

31.6

Intrauterine device (IUD) available in the last 6 months

48.9

Diaphragm available in the last 6 months

2.2

Morning-after pill available in the last 6 months

33.9

Referral for tubal ligation available in the last 6 months

71.8

Referral for vasectomy available in the last 6 months

69.0

Pregnancy test (Pregnosticon or $\beta \mathrm{HCG}$ ) is performed (U)

54.8

Groups of pregnant adolescents $(\mathrm{U})$

Most pregnant women begin prenatal in the 1st trimester of pregnancy

28.8

Routine tests performed for all pregnant women

86.8

Prenatal and postnatal care

Educational groups for pregnant women

85.8

61.3

Time and place of immediate postpartum appointment scheduling

Time and place of late postpartum appointment scheduling

76.1

Women's health includes breast cancer prevention

63.0

91.7

Physical examination for patients with a breast complaint

40.2

Adequacy of criteria for mammogram referral

11.8

Adult care includes prevention of prostate cancer

62.5

Source: The authors, based on the study of Nasser MA (see footnote) and QualiAB 2010

C: activities conducted in the community; U: activities conducted in the unit; STI: sexually transmitted infections; QualiAB: Questionnaire of Quality

Evaluation of Primary Health Care in the Municipalities of São Paulo State

* This table consists of a selection of actions relevant to this discussion. Complete data available in the study of Nasser MA (see footnote). 
The availability of male condoms and oral contraceptives is high. The offer of surgical methods is frequent. On the other hand, female condoms and emergency contraception are scarcer. Most services offer prenatal as a scheduled activity, with admission of pregnant women in the first trimester and performance of the recommended tests. Health education actions for pregnant women are present in most units, some with groups for adolescents. Time and place of immediate postpartum appointment scheduling are usually more appropriate, than for late postpartum. The surveillance of no-show patients is more common for pregnant women when compared to puerperal women. Breast cancer approach often integrates the actions planned for women's health; however, it rarely meets the criteria for mammogram referral. Men's health actions include prevention of prostate cancer in many services.

The overall average performance of the services of PHC for the SRH dimension in São Paulo State is $56.8 \%$; no service has an average higher than $91.9 \%$. The distribution of services in the score for SRH originated a histogram that approaches the normal curve, which indicates the evaluation adequacy and allows the discrimination and description of the performance of the services using the arithmetic mean. Despite considerable variance, the analysis is significant because of the high number of indicators and participating services. Friedman test shows that reproductive health care is the domain with the highest contribution to the SRH dimension, followed by STI/AIDS prevention care and SRH promotion (Figure 1).

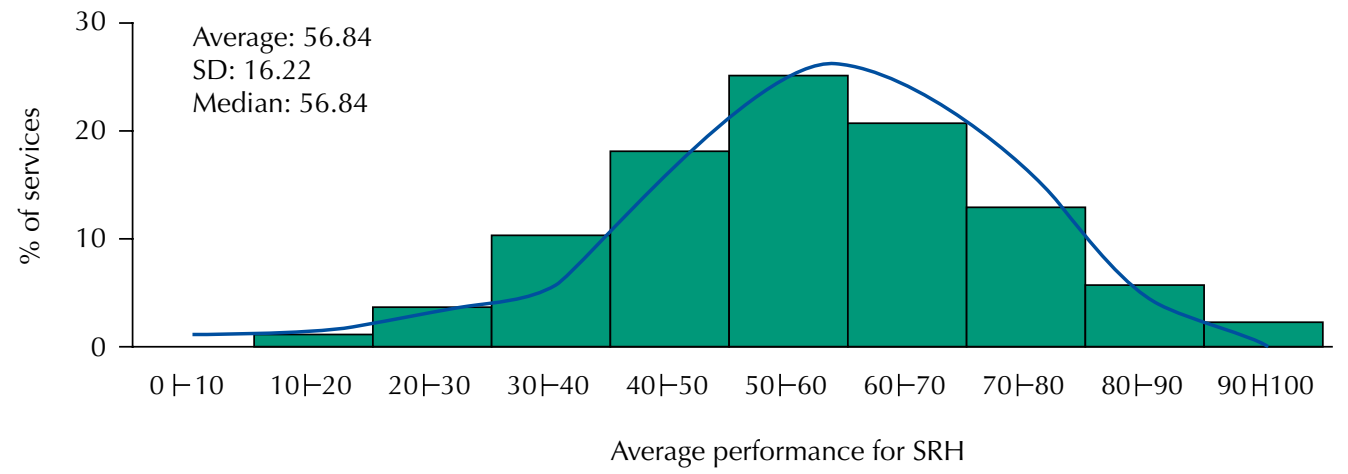

\begin{tabular}{llccc}
\hline Grouping of indicators & Average & SD & Median \\
\hline Domain & SRH Promotion & 36.37 & 22.61 & 32.00 \\
& Health education and networking opportunities & 45.96 & 21.60 & 50.00 \\
\multirow{3}{*}{ Subdomains } & $\begin{array}{l}\text { Investigation of situations of vulnerability and measures to } \\
\text { overcome them }\end{array}$ & 31.12 & 27.39 & 23.08 \\
& Body, sexuality, and reproduction approach & 34.27 & 32.34 & 25.00 \\
Domain & STD/AIDS prevention and care & 62.96 & 16.36 & 65.12 \\
& STI/AIDS prevention and diagnosis & 60.64 & 15.97 & 65.22 \\
& Treatment, partnership with other services, and support to & 59.15 & 23.18 & 63.64 \\
Subdomains & patients with STI/AIDS & & & \\
& Health information and surveillance with opportunity for STI/ & 73.56 & 21.64 & 77.78 \\
& AIDS prevention & 64.86 & 18.64 & 67.74 \\
Domain & Reproductive health care & 62.27 & 21.00 & 69.23 \\
& Reproductive planning & 68.16 & 24.30 & 75.00 \\
Subdomains & Prenatal and postnatal care & 63.88 & 19.71 & 66.74 \\
\hline
\end{tabular}

Source: the authors, based on the study of Nasser MA (see footnote) and QualiAB 2010.

STI: Sexually Transmitted Infections; QualiAB: Questionnaire of Quality Evaluation of Primary Health Care in the Municipalities of São Paulo State; SD: standard deviation.

Friedman test: $p<0.001$ for all values.

Figure 1. Performance of the primary health care (PHC) services in the sexual and reproductive health (SRH) dimensions: comparison between domains and subdomains and distribution of services according to the average performance in SRH $(n=2,735)$. 


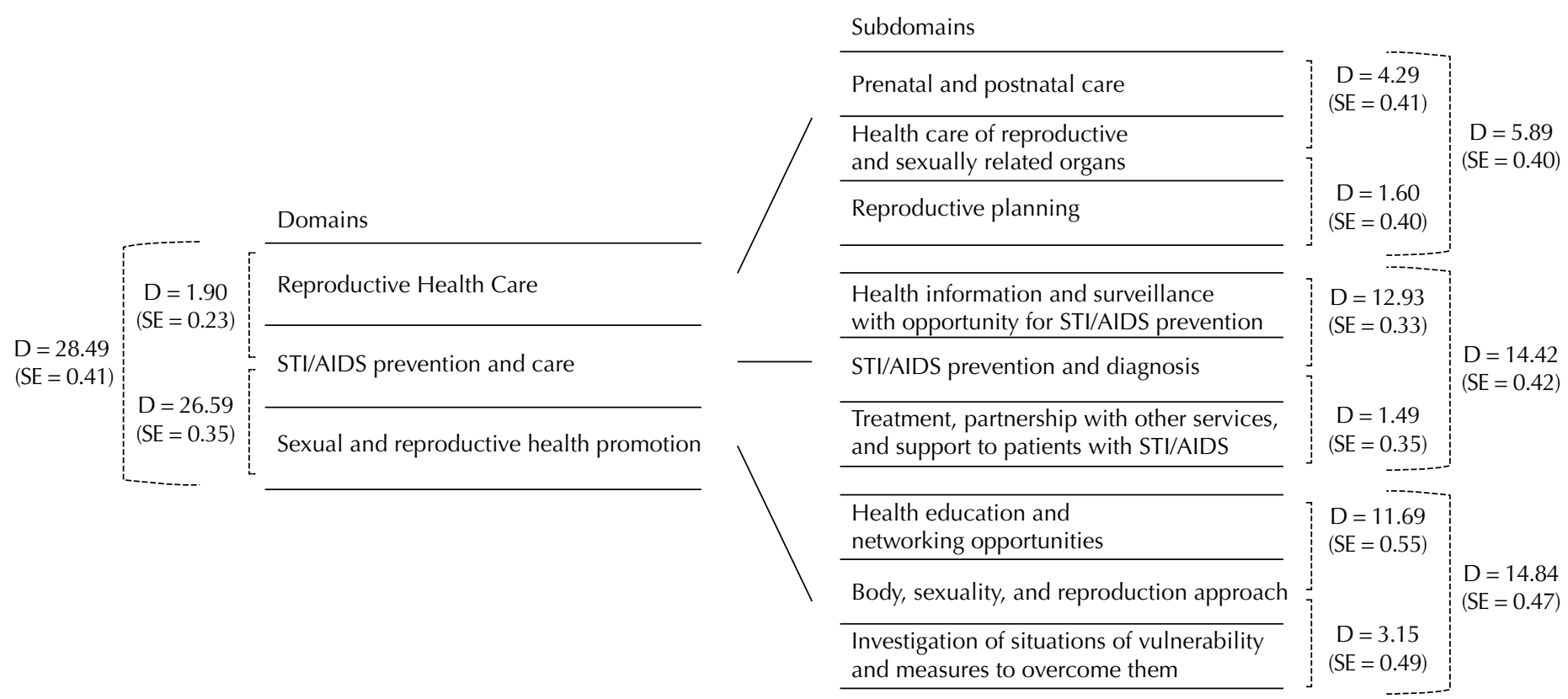

The emphasis of reproductive health care and the relative contribution of the other domains are confirmed by Dunn's comparison, which shows the average difference of each domain of the SRH dimension in relation to the other ones. The comparison between the subdomains shows the distance between their participation in the composition of the domains. The average difference is attributed to the frequency of the actions performed (Figure 2).

The correlation between all domains and subdomains comprising the SRH dimension is positive. The domain of STI/AIDS prevention and care is the only one with correlation greater than 0.6 with the other domains. The same happens with the subdomain of STI/AIDS prevention and diagnosis, which presents correlation greater than 0.5 with the other subdomains (except health care of reproductive and sexually related organs) (Table 3 ).

Source: the authors, based on the study of Nasser MA (see footnote) and QualiAB 2010.

STI: Sexually Transmitted Infections; QualiAB: Questionnaire of Quality Evaluation of Primary Health Care in the Municipalities of São Paulo State; D: average difference; SE: standard error

Test: Dunn's nonparametric multiple comparisons.

The representation of the average difference between each domain or subdomain is not to scale.

Figure 2. Average difference of the performance of primary health care (PHC) services between the domains of sexual and reproductive health $(\mathrm{SRH})$ dimension and between the subdomains that compose each domain.

Table 3. Correlations between the sexual and reproductive health (SRH) dimension and each domain and subdomain to assess the SRH actions of primary health care (PHC) services in the State of São Paulo, Brazil. $(n=2,735)$

\begin{tabular}{|c|c|c|c|c|c|c|c|c|c|c|c|c|c|}
\hline Subdomains, domains, and SRH dimension & $\mathbf{a}$ & $\mathbf{b}$ & c & d & $\mathbf{e}$ & f & $\mathbf{g}$ & $\mathbf{h}$ & $\bar{i}$ & $\bar{j}$ & k & $\mathrm{I}$ & $\mathbf{m}$ \\
\hline a. Health education and networking opportunities & 1 & & & & & & & & & & & & \\
\hline b. Investigation of situations of vulnerability and measures to overcome them & 0.53 & 1 & & & & & & & & & & & \\
\hline c. Body, sexuality, and reproduction approach & 0.48 & 0.63 & 1 & & & & & & & & & & \\
\hline d. STI/AIDS prevention and diagnosis & 0.52 & 0.56 & 0.52 & 1 & & & & & & & & & \\
\hline e. Treatment, partnership with other services, and support to patients with STI/AIDS & 0.39 & 0.40 & 0.38 & 0.55 & 1 & & & & & & & & \\
\hline f. Health information and surveillance with opportunity for STI/AIDS prevention & 0.41 & 0.37 & 0.36 & 0.51 & 0.46 & 1 & & & & & & & \\
\hline g. Reproductive planning & 0.32 & 0.32 & 0.33 & 0.54 & 0.50 & 0.38 & 1 & & & & & & \\
\hline h. Prenatal and postnatal care & 0.44 & 0.41 & 0.43 & 0.54 & 0.44 & 0.49 & 0.48 & 1 & & & & & \\
\hline i. Health care of reproductive and sexually related organs & 0.29 & 0.38 & 0.35 & 0.46 & 0.43 & 0.35 & 0.37 & 0.39 & 1 & & & & \\
\hline j. sexual and reproductive health Promotion & 0.75 & 0.93 & 0.78 & 0.64 & 0.46 & 0.45 & 0.38 & 0.49 & 0.41 & 1 & & & \\
\hline k. STI/AIDS prevention and care & 0.54 & 0.56 & 0.53 & 0.88 & 0.81 & 0.73 & 0.58 & 0.59 & 0.51 & 0.64 & 1 & & \\
\hline I. Reproductive health care & 0.44 & 0.45 & 0.46 & 0.64 & 0.57 & 0.50 & 0.84 & 0.83 & 0.59 & 0.53 & 0.70 & 1 & \\
\hline m. Sexual and reproductive health & 0.66 & 0.75 & 0.68 & 0.83 & 0.71 & 0.65 & 0.66 & 0.72 & 0.57 & 0.84 & 0.91 & 0.83 & 1 \\
\hline
\end{tabular}

Source: the authors, based on the study of Nasser MA (see footnote) and QualiAB 2010.

STI: Sexually Transmitted Infections; QualiAB: Questionnaire of Quality Evaluation of Primary Health Care in the Municipalities of São Paulo State The domains $(j, k, l)$ and the SRH dimension $(m)$ were highlighted in bold to differentiate from the subdomains.

Values in italics correspond to higher correlations found for the domain of STI/AIDS prevention and care and for the subdomain of STI/AIDS prevention and diagnosis with the SRH dimension, other domains and subdomains.

Test: Spearman correlation. $p<0.001$ for all values. 


\section{DISCUSSION}

Concerning the purposes of work in health care ${ }^{3,29}$, the greatest contribution of the domain of reproductive health care for the average performance in SRH reflects the role of tradition in the women's health area in PHC. It reveals the power relations that characterize the care in this group ${ }^{10,17}$, notably regarding the protection of the maternal and child health and female body control ${ }^{10,28}$. The differences in the actions researched and the order of participation between the subdomains - prenatal and postnatal care, health care of reproductive and sexually related organs, and reproductive planning - possibly express an unequal recognition of these practices by both the health sector and the society. Actions seeking maternal and child mortality reduction and screening for neoplasms are regarded as more important than the ones seeking to guarantee reproductive choices in sexuality ${ }^{8,10,28,31}$. Training and know-how in technologies involved in each type of action are different: biomedical actions are more present than those of health communication and education actions ${ }^{11,31}$, with an appropriate offer of exams, compared to groups during prenatal care, for example. Actions commonly happen in the unit rather than in the community. There is a polarization between reproduction and sexuality ${ }^{28}$, as well as inadequacy in how sexual and reproductive rights and gender relations ${ }^{10}$ are addressed indicated by the limitation in the supply of female condoms and emergency contraception.

The domain of STI/AIDS prevention and care occupies the second position in the SRH dimension. The achieved performance is related to PHC assignments in SRH and reflects challenges in its implementation: separation between reproduction and sexuality ${ }^{28}$, stigma related to STI/AIDS ${ }^{8,27}$, and difficulties to conduct care actions guided by the vulnerability and human rights framework ${ }^{4,12,27}$. A greater incorporation of measures for STI/AIDS prevention and diagnosis rather than for care expresses the historical demand for prevention actions in $\mathrm{PHC}^{26}$, as well as low recognition of STI care as its responsability ${ }^{26}$. Consequently, training and adoption of technological tools ${ }^{14,15,26}$ are necessary. The actions of health surveillance and information are a relatively high performance subdomain, with emphasis on data record related to production. However, these data require critical analysis, given the high frequency in the number of collection of Pap smear, in contrast with the low criteria compliance to prescribe the exam.

The lower number of actions of the domain of SRH promotion expresses both the challenge concerning the specific object and the practices of health promotion ${ }^{3,431}$, despite the fact they are PHC responsibility. The promotion of health requires work with social participation, approximation to the territory ${ }^{25}$, health education and communication methodologies ${ }^{11,31}$, interdisciplinarity, and intersectoriality ${ }^{11}$. Some particularities of SRH require understanding complex concepts - such as sexual and reproductive rights ${ }^{7}$, vulnerability ${ }^{4}$, and gender relations $s^{7,10}-$, besides the need to adopt suitable technological tools $s^{15,26}$. There is also disarticulation between reproduction and sexuality ${ }^{28}$ and the predominance of informational over participatory strategies ${ }^{11,31}$. The difference between the educational activities about violence or alcohol and drug use and the follow-up of these cases shows the scarcity of tools for this operation ${ }^{15}$.

The positive correlation between the domains and subdomains of the SRH dimension shows that each one is related to the others, revealing the importance of comprehensiveness ${ }^{3}$ in the SRH care in PHC. The higher correlation of the domain of STI/AIDS prevention and care and, particularly, the subdomain of STI/AIDS prevention and diagnosis (in relation to the other domains and subdomains, respectively) show that both are good indicators for SRH. This characteristic can contribute to a better understanding of how they are implemented in the services. In addition, when taken as an investment and technological proposition focus, these indicators can foster improvements in SRH care practices in PHC. It can be assumed that work with STI/AIDS requires staff prepared to work with sensitive issues ${ }^{8,27}$ capable of addressing complex knowledge and techniques ${ }^{14,15,26}$. This can contribute to the handling of other objects in the health work, which require an approach that take into consideration user autonomy ${ }^{10,11}$, and situations of vulnerability ${ }^{4,27}$, as well as the establishment of interfaces between prescriptive measures and the projects of persons - combining technical attainment and practical success ${ }^{3}$. 
The average performance of units of $56.8 \%$ for the SRH dimension exposes a discrepancy between what is accomplished by the services and what is proposed for $\mathrm{PHC}^{22,32,33}$ in order to achieve population impact ${ }^{30}$. The amount of assignments is a great challenge for $\mathrm{PHC}$, and therefore reduction of expectations could be proposed. However, there are public policies and a SRH program for PHC in Brazil and in the State of São Paulo, which consider SRH actions essential and a responsibility of $\mathrm{PHC}^{16-24}$. Moreover, the very characteristics of $\mathrm{PHC}$, including the articulation of health work purposes ${ }^{3,29}$ and proximity to the territory ${ }^{25}$, make SRH its object ${ }^{13,22}$.

The performance and integration of SRH actions, conducted by PHC services, are indicators of the implementation of the SRH program in PHC. Thus, the analysis of the results points to an incipient implementation. This is due to inadequate recognition of SRH as an object of PHC - not only in its extent, but above all, in the comprehensiveness of SRH -, and the need for review, improvement, and expansion of the incorporation of technologies to handle $\mathrm{SRH}$ in PHC practice.

Regarding the limitations of this study, the assessment focused predominantly on organizational components, which are necessary, yet not sufficient to appreciate quality. The use of previously collected data precluded the inclusion of some objects of the SRH dimension, such as men's health actions and the issue of sexual diversity. The findings cannot be extended to all PHC services in São Paulo: the sample was not done randomly, but rather from the adherence of managers; municipalities with large population were under-represented; the city of São Paulo did not participate in the study. On the other hand, the total number of the participating services was high and there was a significant participation of small municipalities, reflecting both the political and administrative structure of São Paulo, as 81.2\% (524) of municipalities have less than 50,000 inhabitants (IBGE, 2010) and the support of the Program of Primary Health Care Articulators ${ }^{2}$, addressed to small municipalities. The articulation with the SES/SP program, previously mentioned, facilitated the return of results and favored the responsiveness to the recommendations following it ${ }^{5}$.

Methodological possibilities were also present; with emphasis on the construction of a viable assessment, integrating a general questionnaire about PHC with easily understood explanations and recommendations, which may contribute to improving the organization of the work with SRH in PHC. Additionally, the study provided a review and update of the SRH dimension in the new 2016 version of the questionnaire QualiAB. The need to improve $\mathrm{PHC}$ in Brazil is well-known. The diversity of evaluative approaches - as represented by the tools QualiAB, Autoavaliação para a Melhoria do Acesso e da Qualidade da Atenção Básica (AMAQ), Programa Nacional de Melhoria do Acesso e da Qualidade da Atenção Básica (PMAQ), and Primary Care Assessment Tool (PCATool-Brasil) - contribute to this improvement ${ }^{6}$.

\section{CONCLUSIONS AND CONTRIBUTIONS FOR THE SRH PROGRAM IN PHC}

Considering PHC as strategic for SRH is a challenge. This study makes possible the proposition of a theory for the SRH program in PHC, taking into account the action purposes, and presenting priority activities and useful tools for the work. The evaluative framework for SRH in PHC, which, from the assessment of empirical data, was a mediator in the construction of this theory, can be used as a tool, particularly for work planning or future assessments.

With this evaluation framework, the task of assessing practices displaying different characteristics regarding purpose, technology, definition, and tradition in PHC has been fulfilled. It resulted in the creation of an assessment presenting variability of indicators, robust domains and subdomains, and discrimination between services in what concerns performance in SRH actions. These attributions, as well as the insertion of the SRH dimension in a general questionnaire about PHC, make this a viable and replicable assessment. In addition, this assessment shows completeness and usefulness by a combined elaboration of explanations, judgment, and recommendations. 
To affirm that the implementation of SRH actions in PHC of the São Paulo State is incipient - namely, beginning, and therefore still inadequate and insufficient - also means to bet on changes and improvements, which is a possibility inherent in everything that is new. The results and analysis of this assessment may contribute to this process both in the organization of the work in the services and in the management of SRH program in PHC. It is worth mentioning that this assessment allows for a thorough understanding and discussion of the care practices for SRH developed by PHC, the performance of the services, and also the awareness of the domain of STI/AIDS prevention and care as a core indicator for assessments of SRH and a possible focus of technological proposition. Recommendations for the SRH program in the SUS’s PHC of São Paulo State highlight the need to comprehend SRH in PHC, as well as review the work purposes, and by taking into account the distribution of the performance of the services, investments in training and design of tools should be considered.

\section{REFERENCES}

1. Allotey PA, Diniz S, Dejong J, Delvaux T, Gruskin S, Fonn S. Sexual and reproductive health and rights in public health education. Reprod Health Matters. 2011;19(38):56-68. https://doi.org/10.1016/S0968-8080(11)38577-1

2. Andrade MC, Castanheira ERL. Cooperação e apoio técnico entre estado e municípios: a experiência do programa articuladores da atenção básica em São Paulo. Saude Soc. 2011;20(4):980-90. https://doi.org/10.1590/S0104-12902011000400015

3. Ayres JRCM. Organização das ações de Atenção à Saúde: modelos e práticas. Saude Soc. 2009;18 Supl 2:11-23. https://doi.org/10.1590/S0104-12902009000600003

4. Ayres JRCM, Paiva V, França Junior I. From natural history of disease to vulnerability: changing concepts and practices in contemporary public health. In: Parker R, Sommer M, editors. Routledge handbook in global public health. New York: Taylor and Francis; 2011. p.98-107.

5. Castanheira ERL, Nemes MIB, Almeida MAS, Puttini RF, Soares ID, Patrício KP, et al. QualiAB: desenvolvimento e validação de uma metodologia de avaliação de serviços de atenção básica. Saude Soc. 2011;20(4):935-47. https://doi.org/10.1590/S0104-12902011000400011

6. Castanheira ERL, Sanine PR, Zarili TFT, Nemes MIB. Desafios para a avaliação na atenção básica no Brasil: a diversidade de instrumentos contribui para a instituição de uma cultura avaliativa? In: Akerman M, Furtado JP, organizadores. Práticas de avaliação em saúde no Brasil: diálogos. Porto Alegre: Rede Unida; 2015. p.189-231. (Série Atenção Básica e Educação em Saúde).

7. Cook RJ, Dickens BM, Fathalla MF. Saúde reprodutiva e direitos humanos: integrando medicina, ética e direito. Rio de Janeiro: CEPIA; 2004.

8. Cook RJ, Dickens BM. Reducing stigma in reproductive health. Int J Gynecol Obstet. 2014;125 (1);89-92. https://doi.org/10.1016/j.ijgo.2014.01.002

9. Coryn CLS, Noakes LA, Westine CD, Schröter DC. A systematic review of theory-driven evaluation practice from 1990 to 2009. Am / Eval. 2011;32(2):199-226. https://doi.org/10.1177/1098214010389321

10. D'Oliveira AFLP. Saúde e educação: a discussão das relações de poder na atenção à saúde da mulher. Interface (Botucatu). 1999;3(4):105-22. https://doi.org/10.1590/S1414-32831999000100009

11. Donato AF, Rosenburg CP. Algumas idéias sobre a relação educação e comunicação no âmbito da Saúde. Saude Soc. 2003;12(2):18-25. https://doi.org/10.1590/S0104-12902003000200003

12. Ferraz DAS, Nemes MIB. Avaliação da implantação de atividades de prevenção das DST/AIDS na atenção básica: um estudo de caso na Região Metropolitana de São Paulo, Brasil. Cad Saude Publica. 2009;25 Supl 2:240-50. https://doi.org/10.1590/S0102-311X2009001400006

13. Graham A. Sexual health: recent advances in primary care. Br J Gen Pract. 2004 [cited 2017 Mar 7];54(502):382-7. Available from: http://bjgp.org/content/bjgp/54/502/382.full.pdf

14. Grangeiro A, Ferraz D, Calazans G, Zucchi EM, Díaz-Bermúdez XP. O efeito dos métodos preventivos na redução do risco de infecção pelo HIV nas relações sexuais e seu potencial impacto em âmbito populacional: uma revisão da literatura. Rev Bras Epidemiol. 2015;18 Supl 1:43-62. https://doi.org/10.1590/1809-4503201500050005 
15. Mendes-Gonçalves RB. Tecnologia e organização social das práticas de saúde: características tecnológicas do processo de trabalho na rede estadual de centros de saúde de São Paulo. São Paulo: Hucitec, Abrasco;1994.

16. Ministério da Saúde (BR), Secretaria de Políticas de Saúde, Coordenação Nacional de DST e AIDS. Política Nacional de DST/AIDS: princípios e diretrizes. Brasília (DF): Ministério da Saúde; 1999 [cited 2015 Jul 15]. Available from: http://bvsms.saude.gov.br/bvs/publicacoes/cd03_17.pdf

17. Ministério da Saúde (BR), Secretaria de Atenção à Saúde, Departamento de Ações Programáticas Estratégicas. Política Nacional de Atenção Integral à Saúde da Mulher: plano de ação 2004-2007. Brasília (DF): Ministério da Saúde; 2004 [cited 2015 Jul 15]. (Série C. Projetos, Programas e Relatórios). Available from: http://bvsms.saude.gov.br/bvs/publicacoes/politica_nac_atencao_mulher2.pdf

18. Ministério da Saúde (BR), Secretaria de Atenção à Saúde, Departamento de Ações Programáticas Estratégicas. Política Nacional de Direitos Sexuais e Reprodutivos: uma prioridade do Governo. Brasília (DF): Ministério da Saúde; 2005 [cited 2015 Jul 15]. (Série A. Normas e Manuais Técnicos) (Série Direitos Sexuais e Reprodutivos: Caderno, 1). Available from: http://bvsms. saude.gov.br/bvs/publicacoes/cartilha_direitos_sexuais_reprodutivos.pdf

19. Ministério da Saúde (BR), Secretaria de Atenção à Saúde, Departamento de Atenção Básica. HIV/Aids, hepatites e outras DST. Brasília (DF): Ministério da Saúde; 2006 [cited 2015 Jul 16]. (Cadernos de Atenção Básica, 18) (Série A. Normas e Manuais Técnicos). Available from: http://189.28.128.100/dab/docs/publicacoes/cadernos_ab/abcad18.pdf

20. Ministério da Saúde (BR), Secretaria de Atenção à Saúde, Área de Saúde do Adolescente e do Jovem. Marco legal: saúde, um direito de adolescentes. Brasília (DF): Ministério da Saúde; 2007 [cited 2015 Jul 15]. (Série A. Normas e Manuais Técnicos). Available from: http://bvsms.saude. gov.br/bvs/publicacoes/07_0400_M.pdf

21. Ministério da Saúde (BR), Secretaria de Atenção à Saúde, Departamento de Ações Programáticas Estratégicas. Política Nacional de Atenção Integral à Saúde do Homem: princípios e diretrizes. Brasília (DF): Ministério da Saúde; 2008 [cited 2015 Jul 15]. Available from: http://bvsms.saude. gov.br/bvs/publicacoes/politica_nacional_atencao_homem.pdf

22. Ministério da Saúde (BR), Secretaria de Atenção à Saúde, Departamento de Atenção Básica. Saúde sexual e reprodutiva. Brasília (DF): Ministério da Saúde; 2010 [cited 2015 Jul 15]. (Série A. Normas e Manuais Técnicos) (Cadernos de Atenção Básica, 26). Available from: http://189.28.128.100/dab/docs/publicacoes/cadernos_ab/abcad26.pdf

23. Ministério da Saúde (BR), Secretaria de Atenção à Saúde, Departamento de Atenção Básica. PNAB - Política Nacional de Atenção Básica. Brasília (DF): Ministério da Saúde; 2012 [citado 2015 Jul 15]. (Série E. Legislação em Saúde). Available from: http://189.28.128.100/dab/docs/publicacoes/geral/pnab.pdf

24. Ministério da Saúde (BR), Secretaria de Gestão Estratégica e Participativa, Departamento de Apoio à Gestão Participativa. Política Nacional de Saúde Integral de Lésbicas, Gays, Bissexuais, Travestis e Transexuais. Brasília (DF): Ministério da Saúde; 2013 [cited 2015 Jul 15]. Available from: http://bvsms.saude.gov.br/bvs/publicacoes/politica_nacional_saude_lesbicas_gays.pdf

25. Oliveira GN, Furlan PG. A co-produção de projetos coletivos e diferentes "olhares" sobre o território. In: Campos GWS, Guerrero AVP, organizadores. Manual de práticas em atenção básica: saúde ampliada e compartilhada. São Paulo: Hucitec, Abrasco; 2008, p. 247-72.

26. Paula IA, Santos NJS. A prevenção às DST/Aids nos serviços de atenção básica no Estado de São Paulo, 2012. In: Paiva V, Calazans G, Segurado A, organizadores. Vulnerabilidade e direitos humanos: prevenção e promoção da saúde: entre indivíduos e comunidade. Curitiba: Juruá; 2012, 219-38.

27. Peretti-Watel P, Spire B, Obadia Y, Moatti JP; VESPA Group. Discrimination against HIV-Infected people and the spread of HIV: some evidence from France. PLoS One. 2007;2(5):e411. https://doi.org/10.1371/journal.pone.0000411.

28. Pinheiro TF, Couto MT. Sexualidade e reprodução: discutindo gênero e integralidade na Atenção Primária à Saúde. Physis. 2013;23(1):73-92. https://doi.org/10.1590/S0103-73312013000100005

29. Schraiber LB, Mendes-Gonçalves RB. Necessidades de saúde e atenção primária. In: Schraiber LB, Nemes MIB, Mendes-Gonçalves RB, organizadores. Saúde do adulto: programas e ações na unidade básica. 2.ed. São Paulo: Hucitec; 2000. p.29-47.

30. Starfield B. Primary care: an increasingly important contributor to effectiveness, equity, and efficiency of health services. SESPAS report 2012. Gac Sanit. 2012;26 Suppl 1:20-6. https://doi.org/10.1016/j.gaceta.2011.10.009 
31. Teixeira MB, Casanova A, Oliveira CCM, Engstrom EM, Bodstein RCA. Avaliação das práticas de promoção da saúde: um olhar das equipes participantes do Programa Nacional de Melhoria do Acesso e da Qualidade da Atenção Básica. Saude Debate. 2014;38 No Espec:52-68. https://doi.org/10.5935/0103-1104.2014S005

32. United Nations Fund for Women. Platform of Action. Adopted at the International Conference on Women, Beijing, 1995. New York: UNIFEM; 2004.

33. United Nations Population Fund. Programme of Action. Adopted at the International Conference on Population and Development, Cairo, 5-13 September 1994. New York: UNFPA; 2004 [cited 2017 Mar 9]. Available from: https://www.unfpa.org/sites/default/files/event-pdf/ PoA_en.pdf

34. Welfare WS, Lighton L. Mapping of sexual health promotion in North West England, 2008. Public Health. 2011;125(2):101-5. https://doi.org/10.1016/j.puhe.2010.11.002

Funding: The evaluative research that originated the QualiAB questionnaire, and whose data were used in this study, was funded by PPSUS - Programa Pesquisa para o SUS - Gestão Compartilhada em Saúde - Fapesp/SES SP/CNPq/DECIT/MS (Process 05/58652-7).

Authors' Contribution: Design and planning of the study: MAN, MIBN. Conception and coordination of the research line that was the basis of the study: MIBN, MCA, ERLC. Data collection: MAN, MIBN, MCA, ERLC. Statistical analysis: MAN, RRP. Data analysis and interpretation: MAN, MIBN, MCA, ERLC. Preparation of the manuscript: MAN. Review of the manuscript: MAN, MIBN, MCA, ERLC. Approval of final version: MAN, MIBN, MCA, RRP, ERLC. Public responsibility for the article content: MAN, MIBN, MCA, RRP, ERLC.

Acknowledgments: To the QualiAB Research Team (Quality Evaluation of Primary Health Care in the Municipalities of São Paulo State Research Team) for sharing QualiAB data and for having the sexual and reproductive health dimension from this study. To Ana Maroso Alves, for her careful preparation of the tables and figures of the study.

Conflict of Interest: The authors declare no conflict of interest. 